\section{EcoLyst Application Timing and Juice Corrected Soluble Solids (Brix) of Processing Oranges and Grapefruit in Florida}

\author{
Frederick S. Davies, ${ }^{1}$ \\ Ed Stover, ${ }^{2}$ Glenn R. Zalman, ${ }^{1}$ \\ and Scott Ciliento ${ }^{2}$
}

Additional INDEX WORDS. Citrus paradisi, Citrus sinensis, methyl butyl tertiary amine, MBTA, N-N-diethyl-2-(4-methylbenzyloxy) ethylamine hydrochloride, plant growth regulators, PGR

Summary. EcoLyst, a formulation of N-N-diethyl-2-(4-methylbenzyloxy) ethylamine hydrochloride containing 1 $\mathrm{g} / \mathrm{fl} \mathrm{oz}\left[4.5 \mathrm{oz} / \mathrm{gal}\left(33.8 \mathrm{~g} \cdot \mathrm{L}^{-1}\right)\right]$ a.i., is a plant growth regulator that has been reported to increase soluble solids concentration (SSC) in juice oranges by $0.6 \%$ to $1.2 \%$. Our objectives were to determine the effectiveness of EcoLyst application for increasing SSC in Florida oranges (Citrus sinensis) and grapefruit (C. paradisi), and to identify the optimum rate and time of application. Experiments were conducted for three seasons using 'Hamlin,' 'Pineapple,' and 'Valencia' sweet oranges; and for two seasons using 'Flame,' 'Marsh,' and 'Ray Ruby' grapefruit, all in commercial groves. EcoLyst was applied at 6 and $12 \mathrm{fl} \mathrm{oz} /$ acre $(0.44$ and $\left.0.88 \mathrm{~L} \cdot \mathrm{ha}^{-1}\right)$ for oranges and 16 and 32 ppm $\left(\mathrm{mg} \cdot \mathrm{L}^{-1}\right)$ [effectively 9 and $18 \mathrm{fl}$ oz/acre $\left(0.66\right.$ and $\left.1.32 \mathrm{~L} \cdot \mathrm{ha}^{-1}\right)$ in most sprays] for grapefruit, and included Silwet L-77 adjuvant at $\mathbf{0 . 0 5 \%}$. Applications were made at several stages of development from prebloom to initial fruit set. In all cases, SSC was determined as juice corrected SSC, by adjusting refractometer readings based on titratable acidity. In 13 trials with sweet orange only five displayed significant increases in SSC $(P \leq \mathbf{0 . 0 5})$ resulting from EcoLyst application.

This research was supported by the Florida Experiment Station, and approved for publication as journal series R-09608.

${ }^{1}$ Horticultural Sciences Department, University of Florida, Gainesville, FL 32611

${ }^{2}$ Indian River Research and Education Center, University of Florida, Ft. Pierce, FL 34945.
Two additional trials produced SSC increases significant at $P<0.10$. Even where significant increases in SSC occurred they were typically observed in only one harvest and at one time of application and were always relatively low in magnitude (highest increase over controls was $\mathbf{0 . 3 8 \%}$ ). No rate or timing of EcoLyst application was consistently associated with best response, although eight of nine SSC increases observed in orange occurred with applications ranging from prebloom to $25 \%$ open flowers. Only one significant increase in SSC was observed in five trials with grapefruit. In these studies, increases in SSC resulting from EcoLyst application were neither sufficiently consistent nor large enough to justify a recommendation for commercial use in Florida citrus.

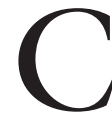
itrus growers in Florida are often paid for processing fruit based on the total sugar content, which is a function of percent juice, soluble solids content corrected for juice acidity [SSC $\left({ }^{\circ}\right.$ Brix $\left.)\right]$ as well as total fruit weight. EcoLyst, (GMJA Specialties, Bradenton, Fla.), is a tertiary amine plant growth regulator developed by the USDA and Tropicana, Inc. (Bradenton, Fla.) (Keithly et al., 1991), and was reported to increase SSC of juice oranges by as much as $1.2 \%$, with average increases of $0.6 \%$ (Campbell et al., 1999). Such large increases in SSC offer the potential to increase net returns to Florida citrus growers, and because of its favorable toxicological profile, EcoLyst was labeled for use in juice oranges in 1999 (Environmental Protection Agency, 1999). In the label and published report, it was recommended that EcoLyst be applied at 50\% flower opening to full bloom, but response to EcoLyst has been somewhat variable, with some studies suggesting that application before midbloom may increase EcoLyst effectiveness (Keithly et al., 2003). The objectives of this study were to assess the benefit of using EcoLyst for Florida oranges and grapefruit and to determine the optimum time and rate for EcoLyst application to increase SSC.

\section{Materials and methods FACTORS CONSISTENT IN ALL OR- ANGE EXPERIMENTS}

All orange trees were sprayed using a Solo backpack sprayer (Solo, Inc., Newport News, Va. at 1 gal $(3.8 \mathrm{~L})$ per tree exceptat Arcadia('Pineapple') where 1.3 gal $(4.9 \mathrm{~L})$ per tree were applied due to 
the large tree size. All EcoLyst treatments with orangesincluded $0.05 \%$ Silwet L-77 adjuvant. At harvest, a randomly selected 23 fruit sample was collected around the tree at a 3 to $6 \mathrm{ft}(0.9-1.8 \mathrm{~m})$ height. A standard sample typically consists of 20 fruit of similar size (Reitz and Sites, 1948). The three extra fruit were used to remove any residual juice from the juicer before each new sample was run. Fruit were taken to Gainesville, Fla., for analysis. Fruit were weighed and then juiced using an FMC Fresh and Squeeze juicer(FMC Inc., Lakeland, Fla.), following which juice weight was determined. A refractometer (Bellingham and Stanley, Tunbridge Wells, UK) was used to determine uncorrected SSC. Titratable acidity (TA) was determined using an automatic titrator (Denver Instruments, Denver, Col.). All SSC values presented in this paper have been corrected for TA levels. Corrected SSC was calculated by adjusting SSC for TA levels and SSC: TA ratio was calculated (Wardowski et al., 1995). Readers should note that increases in corrected SSC resulting from EcoLyst treatment are expressed as net increases in SSC (\%SSC EcoLyst-\%SSC control) rather than as a percentage of the control value [(\%SSC EcoLyst - \%SSC Control) $/ \%$ SSC control $\times 100]$.

ORANGE RATE AND TIMING EXPERIMENT, 1999-2000

Groveland 'HamLin' ORANGe. The grove consisted of 15-year-old 'Hamlin' orange (Citrus sinensis) trees on Carrizo citrange (C. sinensis $\mathrm{x}$ Poncirus trifoliata) rootstock planted at a $15 \times 20 \mathrm{ft}(4.6 \times 6.1 \mathrm{~m})$ spacing within and between rows [ 145 trees/acre (358 trees/ha)]. EcoLyst was applied at two rates, 6 and $12 \mathrm{fl} \mathrm{oz} /$ acre at two times, 18 Mar. at $75 \%$ to $100 \%$ open flowers and on 31 Mar. 1999 at initial fruit set. Harvest samples were collected on 12 Oct., 9 Nov., and 14 Dec. 1999 and 21 Jan. 2000.

Arcadia 'Hamlin' orange. The grove consisted of 13-year-old 'Hamlin' orange trees on Carrizo citrange rootstock. Trees were grown on double beds at an $8 \times 20 \mathrm{ft}(2.4 \times 6.1$ $\mathrm{m})$ spacing within and between rows [272 trees/acre (672 trees/ha)]. The same two rates of EcoLyst were used as at Groveland. EcoLyst was applied on 17 Mar. 1999 at $30 \%$ to $60 \%$ open flowers and on 25 Mar. 1999 at 50\% to $75 \%$ open flowers. Harvest samples were collected on 12 Oct., 10 Nov., 15 Dec.1999, and 20 Jan. 2000.

ArCadia 'PINEAPPle' orange.
The grove consisted of 13-year-old 'Pineapple' orange trees on sour orange (C. aurantium) rootstock planted at a $15 \times 30 \mathrm{ft}$ spacing within and between rows [97 trees/acre (240 trees/ha)]. The same two EcoLyst rates were used as above. Treatments were applied on 16 Mar. 1999 at $30 \%$ to $50 \%$ open flowers and on 25 Mar. 1999 at 50\% open flowers. Harvest samples were collected on 10 Nov. and 15 Dec. 1999, and 20 Jan. 2000.

Arcadia 'Valencia' Orange. The grove consisted of 25-year-old 'Valencia' orange trees on Carrizo citrange rootstock planted at a $15 \times 30 \mathrm{ft}$ spacing within and between rows. The same two EcoLyst rates were used as above. Treatments were applied on 16 Mar. 1999 at 10\% open flowers and on 25 Mar. 1999 at $25 \%$ open flowers. Harvest samples were collected on 19 Jan. 2000.

LAKE WALES 'VALENCIA' ORANGE. The grove consisted of 11 -year-old ' $\mathrm{Va}$ lencia' orange trees on Carrizo citrange rootstock planted at a $15 \times 30 \mathrm{ft}$ spacing within and between rows. The same EcoLyst rates were used as above. Treatments were applied on 25 Mar. at $<10 \%$ open flowers and on 6 Apr. 1999 at $20 \%$ to $50 \%$ open flowers. Harvest samples were collected on 26 Jan. and 1 Mar. 2000.

\section{EXPERIMENTAL DESIGN AND STATIS-} TICAL ANALYSES

All experiments were designed as a 2 (rate) $\times 2$ (timing) factorial with a single nonsprayed control (five treatments). Within each location one individual tree per treatment was used in each of 10 blocks in a randomized complete block design ( 50 trees per site). Data were analyzed by anaylsis of variance (ANOVA) by harvest date and treatment. Further mean separation was performed using Duncan's multiple range test at $P \leq 0.05$ and contrast analyses (SAS Institute, Cary, N.C.).

ORANGE TIMING EXPERIMENTS, 2000-01

Groveland 'Hamlin' ORANGe. The same grove was used in 2000-01 as in the previous year, but different trees were selected. Cultivar, rootstock, tree density, and application methods were the same as used in 1999-2000. Based on the previous year's research, EcoLyst was applied at $6 \mathrm{fl} \mathrm{oz} /$ acre along with $0.05 \%$ Silwet L-77 adjuvant ( Helena Chemical, Memphis, Tenn.) on $23 \mathrm{Feb}$. (prebloom), 7 Mar. (10\% open flowers), 21 Mar. (50\% open flowers), 29 Mar. (50\% petal fall), and 4 Apr. 2000
( $100 \%$ petal fall). Harvest samples were collected on 2 Nov. and 13 Dec. 2000, and 16 Jan. 2001.

Bartow 'HamLin' ORANGE. The grove consisted of 15-year-old 'Hamlin' orange trees on Carrizo citrange rootstock planted at a $12 \times 24 \mathrm{ft}(3.7$ $\times 7.3 \mathrm{~m})$ spacing within and between rows [ 151 trees/acre (373 trees/ha)]. EcoLyst was applied as described above on 23 Feb. (prebloom), 7 Mar. (10\% open flowers), 21 Mar. (full bloom), 29 Mar. (50\% petal fall), and 4 Apr. 2000 (initial fruit set). Harvest samples were collected on 26 Oct. and 28 Nov. 2000 , and 9 Jan. 2001.

Bartow 'VALENCIA' ORANGe. The grove consisted of 15-year-old 'Valencia' orange trees on Carrizo citrange rootstock planted at a $12 \times 24 \mathrm{ft}$ spacing within and between rows. EcoLyst was applied as described above on $23 \mathrm{Feb}$ (prebloom), 7 Mar. (10\% open flowers), 21 Mar. (45\% open flowers), 29 Mar. (55\% petal fall), and 4 Apr. 2000 ( $100 \%$ petal fall). Harvest samples were collected on 27 Mar. 2001.

LAKE WALES 'VALENCIA' ORANGE. The grove consisted of 12 -year-old 'Valencia' orange trees on Carrizo citrange rootstock planted at a $12 \times 24 \mathrm{ft}$ spacing within and between rows. EcoLyst was applied as described above on $23 \mathrm{Feb}$. (prebloom), 7 Mar. (10\% open flowers), 21 Mar. (65\% open flowers), $29 \mathrm{Mar}$ (full bloom), and 4 Apr. 2000 (100\% petal fall). Harvest samples were collected on 20 Feb. and 27 Mar. 2001.

\section{EXPERIMENTAL DESIGN AND STATIS- TICAL ANALYSIS}

All experimental sites were arranged as split plot in time studies with time of application as the main plot and harvest time as the subplot. Within each location one individual tree per treatment was in each block, arranged as a randomized complete block design with 10 blocks per location (50 trees total). Data were analyzed by ANOVA by application time and harvest date. Further mean separation was performed using Duncan's multiple range test at $P \leq 0.05$, and contrast analyses (SAS Institute, Cary, N.C.).

ORANGE TIMING EXPERIMENTS, 2001-02

Timing experiments in 2001-02 were conducted at the same locations and on the same trees as used in 2000-01 with the exception of Groveland where severe freeze damage had occurred and the crop was reduced significantly. A substitute site 
was chosen at Fellsmere, Fla. EcoLyst was applied at $6 \mathrm{fl} \mathrm{oz} /$ acre along with $0.05 \%$ Silwet L-77 as described previously. Application times and percent flowering were as follows:

Bartow 'HAMLIN' ORANGe. Treatments were applied on 20 Feb. (prebloom), $28 \mathrm{Feb}$. (15\% open flowers), 7 Mar. (25\% open flowers), 14 Mar. (full bloom), and 23 Mar. 2001 (initial fruit set). Harvest samples were collected on 24 Oct. and 27 Nov. 2001, and 8 Jan. 2002.

Fellsmere 'Hamlin' orange. The grove consisted of 19-year-old 'Hamlin' orange trees on Carrizo citrange rootstock planted at a 15 $\times 30 \mathrm{ft}$ spacing within and between rows. Treatments were applied on 20 Feb. (prebloom), 26 Feb. (25\% open flowers), 8 Mar. (petal fall), 14 Mar. (initial fruit set), and 23 Mar. 2001 (post fruit set). Harvest samples were collected on 30 Oct. and 4 Dec. 2001, and 15 Jan. 2002.

Bartow 'VAlencia' ORANGe. Treatments were applied on $20 \mathrm{Feb}$. (prebloom), 28 Feb. (<10\% open flowers), 7 Mar. ( $<25 \%$ open flowers), 13 Mar. (full bloom), and 23 Mar. 2001 (initial fruit set). Harvest samples were collected on 7 and 12 Mar. 2002.

LAKe WaLes 'VALENCIA' ORANGe. Treatments were applied on 20 Feb. (prebloom), 26 Feb (40\% open flowers), 8 Mar. (<10\% open flowers), 14 Mar. (full bloom), and 23 Mar. 2001 (initial fruit set). Harvest samples were collected on 6 and 12 Mar. 2002.

\section{GRAPEFRUIT RATE AND TIMING EX-} PERIMENTS, 1999-2001

In each experiment, EcoLyst was applied at two rates [16 and $32 \mathrm{ppm}$ (effectively 9 and $18 \mathrm{floz} /$ acre in most sprays)] and at two times, prebloom (primarily pinhead flower buds present) and early to late bloom (20\% to 90\% open flowers). Grapefruit trees were sprayed using a commercial orchard three-point hitch sprayer (Rear's Manufacturing Co., Eugene, Ore.) at 150 to $175 \mathrm{gal} / \mathrm{acre}$ (1403.0 to 1636.9 $\mathrm{L} \cdot \mathrm{ha}^{-1}$ ) based on tree size. At two or three harvest dates, a randomly selected 30 fruit sample was collected around each tree at a 3 to $6 \mathrm{ft}$ height. Fruit were analyzed as described for oranges except that samples were squeezed using an FMC State Test Juicer.

Ft. Pierce 'Ray Ruby' grapeFRUIT. The grove consisted of 5-year-old 'Ray Ruby' grapefruit on Gou Tou (unknown Citrushybrid) rootstock planted at a $15 \times 25 \mathrm{ft}(4.6 \times 7.6 \mathrm{~m})$ spacing within and between rows [116 trees/ acre (286 trees/ha)] on double row beds. Treatments were applied on 25 Mar. at prebloom (no flowers open, all at pinhead) and on 14 Apr. 1999 at 20\% to $50 \%$ open flowers. Harvest samples were collected on 22 Sept. 1999, 23 Dec. 1999, and 7 Feb. 2000.

The same treatments were applied to each tree in 2000, with applications on 8 Mar. at prebloom (no flowers open, most at pinhead, many showing white petals) and on 17 Mar. at 20\% to $70 \%$ open flowers. Harvest samples were collected on 16 Oct. 2000 and 23 Jan. 2001.

LOXAHATCHEE 'FlAME' GRAPEFRUIT. The grove consisted of 9-yearold 'Flame' grapefruit on Swingle citrumelo (C. paradisi $x$ Poncirus trifoliata) rootstock planted at a $15 \times 25 \mathrm{ft}$ spacing within and between rows on double row beds. Treatments were applied on 23 Mar. at prebloom (no flowers open, all at pinhead) and on 14 Apr. 1999 at 20\% to $50 \%$ open flowers. Harvest samples were collected on 22 Sept. and $23 \mathrm{Dec}$. 1999 and 7 Feb. 2000.

The same treatments were applied to each tree in 2000, with applications on 16 Mar. at prebloom (very few flowers open, most at pinhead) and on 24 Mar. at $40 \%$ to $90 \%$ open flowers. Harvest samples were collected on 16 Oct. 2000 and 24 Jan. 2001.

Ft. Pierce 'MARsh' grapefruit. The grove consisted of 5-year-old 'Marsh' grapefruit on Sun Chu Sha mandarin (C. reticulata) rootstock planted at a $15 \times 25 \mathrm{ft}$ spacing within and between rows on double row beds. Treatments were applied on 8 Mar. at prebloom (no flowers open, most at pinhead, some showing white petals) and on 21 Mar. 2000 at $20 \%$ to $50 \%$ open flowers. Harvest samples were collected on 17 Oct. 2000 and 23 Jan. 2001.

EXPERIMENTAL DESIGN AND STATISTICAL ANALYSES. All experiments were designed as a 2 (rate) $\times 2$ (timing) factorial with a single nonsprayed control (five treatments). Within each location one individual tree per treatment was used in each of 10 blocks in a randomized complete block design ( 50 trees per site). Data were analyzed by ANOVA by harvest date and treatment. Further mean separation was performed using Duncan's multiple range test at $P \leq 0.05$, and contrast analyses (SAS Institute, Cary, N.C.).

\section{Results and Discussion}

ORANGE RATE AND TIMING EXPERIMENT, 1999-2000. Overall, EcoLyst increased SSC in three of five sites tested, but at only a single rate, spray timing and harvest date of the 8 to 12 tested at each site. Of the three instances in which EcoLyst increased SSC, two were at the $6 \mathrm{oz} /$ acre and one at the $12 \mathrm{oz} /$ acre rate, and all three occurred when application was made with $<50 \%$ open flowers.

EcoLyst application did not affect juice SSC on any of four harvest dates for 'Hamlin' oranges at Groveland or Arcadia (data not shown). SSC values were similar at both sites and ranged from a mean of $9.15 \%$ on 12 Oct. to $11.20 \%$ on 20 to 21 Jan. EcoLyst application early (16 Mar., $30 \%$ to $50 \%$ open flowers) at $6 \mathrm{oz} /$ acre increased SSC by $0.38 \%$ over controls for the 15 Dec. harvest for 'Pineapple" oranges in Arcadia (Table 1). This was the greatest increase in corrected SSC observed in our study. EcoLyst did not significantly

Table 1. Effects of EcoLyst rates and application timing on juice soluble solids concentration (SSC) of 'Pineapple' oranges in Arcadia, Fla., 1999-2000.

\begin{tabular}{lcccc}
\hline & & \multicolumn{3}{c}{ Harvest date } \\
\cline { 3 - 5 } Treatment & $\begin{array}{c}\text { Date }(\text { rate }) \\
\text { (fl oz/acre) }\end{array}$ & 10 Nov. & 15 Dec. & 20 Jan. \\
\cline { 3 - 5 } & 16 Mar. (6) & $9.20 \mathrm{a}$ & $10.55 \mathrm{a}$ & $11.06 \mathrm{a}$ \\
1 & 16 Mar. (12) & $9.06 \mathrm{a}$ & $10.35 \mathrm{a}$ & $11.01 \mathrm{a}$ \\
2 & 25 Mar. (6) & $9.17 \mathrm{a}$ & $10.49 \mathrm{a}$ & $10.82 \mathrm{a}$ \\
3 & 25 Mar. (12) & $9.24 \mathrm{a}$ & $10.23 \mathrm{a}$ & $10.97 \mathrm{a}$ \\
4 & Control & $9.09 \mathrm{a}$ & $10.17 \mathrm{a}$ & $10.91 \mathrm{a}$ \\
5 & & NS & 5 vs. $1(P=0.04)$ & $\mathrm{NS}$ \\
\hline Contrasts $^{\mathrm{x}}$ & &
\end{tabular}

${ }^{2} 1 \mathrm{fl} \mathrm{oz} /$ acre formulation $=0.035 \mathrm{oz} /$ acre a.i. $=2.47 \mathrm{~g} \cdot \mathrm{ha}^{-1}$ a.i.

ySC values are corrected for titratable acidity. Means within columns followed by the same letter are not significantly different by Duncan's multiple range test at $P \leq 0.05$. Means presented are for 10 trees per treatment and a 20 fruit sample per tree.

${ }^{x}$ Contrast analysis was run on each EcoLyst treatment vs. the control. Only contrasts with $P<0.10$ are listed, along

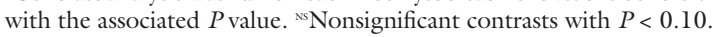


Table 2. Effects of EcoLyst rates and application timing on juice soluble solids concentration (SSC) of 'Valencia' oranges in Arcadia, Fla., 1999-2000.

\begin{tabular}{|c|c|c|}
\hline Treatment & $\begin{array}{l}\text { Date (rate) } \\
(\text { fl oz/acre) }\end{array}$ & $\begin{array}{l}\text { Harvest } \\
19 \text { Jan. } \\
\text { SSC }^{y}(\%)\end{array}$ \\
\hline 1 & 16 Mar. (6) & $11.04 \mathrm{a}$ \\
\hline 2 & 16 Mar. (12) & $10.93 \mathrm{a}$ \\
\hline 3 & 25 Mar. (6) & $11.00 \mathrm{a}$ \\
\hline 4 & 25 Mar. (12) & $11.02 \mathrm{a}$ \\
\hline 5 & Control & $10.76 \mathrm{a}$ \\
\hline Contrasts $^{\mathrm{x}}$ & & 5 vs. $1(P=0.06)$ \\
\hline
\end{tabular}

Table 3. Effects of EcoLyst rates and application timing on juice soluble solids concentration (SSC) of 'Valencia' oranges in Lake Wales, Fla., 1999-2000.

\begin{tabular}{|c|c|c|c|}
\hline \multirow[b]{3}{*}{ Treatment } & \multirow{3}{*}{$\begin{array}{l}\text { Date (rate) } \\
(\text { fl oz/acre })^{\mathrm{z}}\end{array}$} & \multicolumn{2}{|c|}{ Harvest } \\
\hline & & 26 Jan. & 1 Mar. \\
\hline & & \multicolumn{2}{|c|}{$\mathrm{SSC}^{\mathrm{y}}(\%)$} \\
\hline 1 & 25 Mar. (6) & $11.61 \mathrm{~b}$ & $12.15 \mathrm{a}$ \\
\hline 2 & 25 Mar. (12) & $11.95 \mathrm{a}$ & $12.40 \mathrm{a}$ \\
\hline 3 & 6 Apr. (6) & $11.63 \mathrm{~b}$ & $12.30 \mathrm{a}$ \\
\hline 4 & 6 Apr. (12) & $11.63 \mathrm{~b}$ & $12.19 \mathrm{a}$ \\
\hline 5 & Control & $11.57 \mathrm{~b}$ & $12.26 \mathrm{a}$ \\
\hline Contrasts $^{x}$ & & 5 vs. $2(P=0.001)$ & Ns \\
\hline
\end{tabular}

$\mathrm{z}_{1} \mathrm{fl} \mathrm{oz} /$ acre formulation $=0.035 \mathrm{oz} /$ acre a.i. $=2.47 \mathrm{~g} \cdot \mathrm{ha}^{-1}$ a.i.

ySSC values are corrected for titratable acidity. Means within columns followed by the same letter are not significantly different by Duncan's multiple range test at $P \leq 0.05$. Means presented are for 10 trees per treatment and a 20 fruit sample per tree.

'Contrast analysis was run on each EcoLyst treatment versus the control. Only contrasts with $P<0.10$ are listed, along with the associated $P$ value.

NNonsignificant contrasts with $P<0.10$

affect SSC on the other harvest dates. Similarly, early EcoLyst application on 16 Mar. in Arcadia (6 oz/acre) and 25 Mar. in Lake Wales (12 oz/acre) increased SSC of 'Valencia' over controls at Arcadia on 19 Jan. $(0.28 \%)$ (Table 2 ) and at Lake Wales on 26 Jan. $(0.38 \%)$ (Table 3 ). The $12 \mathrm{oz} /$ acre and $6 \mathrm{oz} /$ acre rates were not markedly different in SSC effects, and earlier studies (Keithly et al., 2003), economics, and regulatory considerations all favored use of $6 \mathrm{oz} / \mathrm{acre}$ in subsequent experiments.

Orange timing experiment, 2000-01. EcoLyst again did not affect SSC for 'Hamlin' oranges at Groveland at any of the three harvest dates (data not shown). Values for SSC were similar to those of 1999-2000. Similarly, EcoLyst did not affect SSC for 'Valencia' oranges in Bartow or Lake Wales at any harvest date (data not shown). However, EcoLyst application prebloom $(23 \mathrm{Feb}$. 2000) and at initial fruit set (4 Apr.) increased SSC of 'Hamlin' oranges at Bartow over control values by $0.26 \%$ and $0.25 \%$, respectively on 26 Oct. Prebloom EcoLyst application increased SSC by $0.28 \%$ on 28 Nov. 2000 , and $0.30 \%$ on 9 Jan. 2001 ( $P \leq 0.07)$ (Table $4)$. This was the only location where EcoLyst consistently increased juice SSC at all harvest times.

'Hamlin' trees at Bartow had lower average SSC than those at Groveland and showed increases in SSC of $0.26 \%$ to $0.30 \%$. Possibly EcoLyst is more effective in increasing SSC of low SSC fruit than fruit with high SSC. At this site, application of EcoLyst was effective in increasing SSC even when applied before any flowers were visible.

ORANGE RATE AND TIMING EXPERIMENT, 2001-02. Application timing had no affect on SSC for 'Valencia' trees at Lake Wales and Bartow (data not shown). However, prebloom application increased SSC by $0.22 \%$ over controls for 'Hamlin' fruit at Bartow on 24 Oct. $(P=0.09)$ (Table 5$)$. There were no significant differences among treatments on the 27 Nov. and 8 Jan. harvest dates.

In contrast, EcoLyst application at $25 \%$ open flowers increased SSC of 'Hamlin' oranges by $0.28 \%$ over control values at the 30 Oct. harvest in Fellsmere (Table 6). There were also differences between the control and initial fruit set treatment $(P=0.06)$ on Oct. 30 and the control and petal fall and initial fruit set treatments on $4 \mathrm{Dec}$. In these instances,

Table 4. Effects of EcoLyst application ( $6 \mathrm{fl} \mathrm{oz} / \mathrm{acre})^{\mathrm{z}}$ timing on juice soluble solids concentration (SSC) of 'Hamlin' oranges in Bartow, Fla., 2000-01.

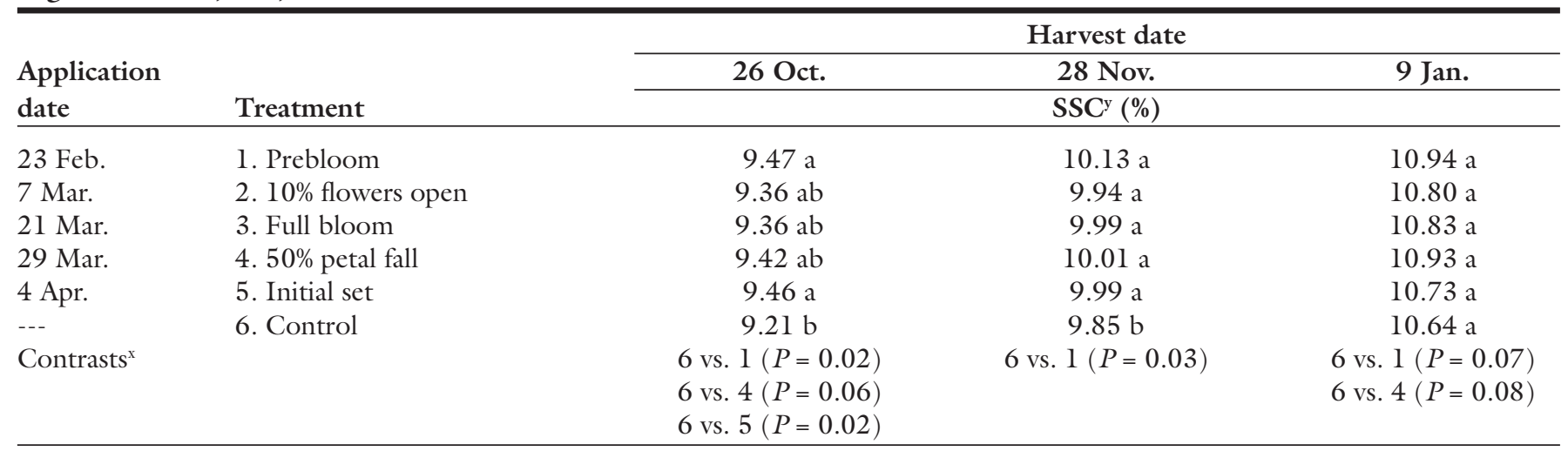

${ }^{2} 6 \mathrm{fl} \mathrm{oz} /$ acre formulation $=0.21 \mathrm{oz} /$ acre a.i. $=14.8 \mathrm{~g} \cdot \mathrm{ha}^{-1}$ a.i.

ySC values are corrected for titratable acidity. Means within columns followed by the same letter are not significantly different by Duncan's multiple range test at $P \leq 0.05$. Means presented are for 10 trees per treatment and a 20 fruit sample per tree.

${ }^{x}$ Contrast analysis was run on each EcoLyst treatment versus the control. Only contrasts with $P<0.10$ are listed, along with the associated $P$ value. 
Table 5. Effects of EcoLyst application (6 fl oz/acre) $)^{\mathrm{z}}$ timing on juice soluble solids concentration (SSC) of 'Hamlin' oranges in Bartow, Fla., 2001-02.

\begin{tabular}{|c|c|c|c|c|}
\hline \multirow{3}{*}{$\begin{array}{l}\text { Application } \\
\text { date }\end{array}$} & \multirow[b]{3}{*}{ Treatment } & \multicolumn{3}{|c|}{ Harvest date } \\
\hline & & 24 Oct. & 27 Nov. & 8 Jan. \\
\hline & & \multicolumn{3}{|c|}{ SSC $^{y}(\%)$} \\
\hline 20 Feb. & 1. Prebloom & $9.66 \mathrm{a}$ & $10.28 \mathrm{a}$ & $11.15 \mathrm{a}$ \\
\hline 28 Feb. & 2. $15 \%$ flowers open & $9.58 \mathrm{a}$ & $10.33 \mathrm{a}$ & $10.98 \mathrm{a}$ \\
\hline 7 Mar. & 3. $25 \%$ flowers open & $9.61 \mathrm{a}$ & $10.34 \mathrm{a}$ & $11.25 \mathrm{a}$ \\
\hline 14 Mar. & 4. Full bloom & $9.57 \mathrm{a}$ & $10.42 \mathrm{a}$ & $11.07 \mathrm{a}$ \\
\hline 23 Mar. & 5. Initial set & $9.61 \mathrm{a}$ & $10.34 \mathrm{a}$ & $11.13 \mathrm{a}$ \\
\hline--- & 6. Control & $9.44 \mathrm{a}$ & $10.36 \mathrm{a}$ & $11.10 \mathrm{a}$ \\
\hline \multicolumn{2}{|c|}{ Contrasts $^{x}$} & 6 vs. $1(P=0.09)$ & NS & NS \\
\hline
\end{tabular}

${ }^{2} 6 \mathrm{fl} \mathrm{oz} /$ acre formulation $=0.21 \mathrm{oz} /$ acre a.i. $=14.8 \mathrm{~g} \cdot \mathrm{ha} \mathrm{a}^{-1}$ a.i.

ySSC values are corrected for titratable acidity. Means within columns followed by the same letter are not significantly different by Duncan's multiple range test at $P \leq 0.05$. Means presented are for 10 trees per treatment and a 20 fruit sample per tree.

${ }^{x}$ Contrast analysis was run on each EcoLyst treatment versus the control. Only contrasts with $P<0.10$ are listed, along with the associated $P$ value

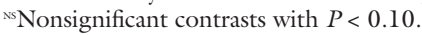

Table 6. Effects of EcoLyst application $(6 \mathrm{fl} \mathrm{oz} / \mathrm{acre})^{\mathrm{z}}$ timing on juice soluble solids concentration (SSC) of 'Hamlin' oranges in Fellsmere, Fla., 2001-02.

\begin{tabular}{|c|c|c|c|c|}
\hline \multirow{3}{*}{$\begin{array}{l}\text { Application } \\
\text { date }\end{array}$} & \multirow[b]{3}{*}{ Treatment } & \multicolumn{3}{|c|}{ Harvest date } \\
\hline & & 30 Oct. & 4 Dec. & 15 Jan. \\
\hline & & \multicolumn{3}{|c|}{ SSC $^{y}(\%)$} \\
\hline $20 \mathrm{Feb}$. & 1. Prebloom & $10.92 \mathrm{ab}$ & $12.15 \mathrm{ab}$ & $13.54 \mathrm{a}$ \\
\hline 26 Feb. & 2. $25 \%$ flowers open & $11.12 \mathrm{a}$ & $12.24 \mathrm{a}$ & $13.42 \mathrm{a}$ \\
\hline 8 Mar. & 3. Petal fall & $10.79 \mathrm{bc}$ & $11.81 \mathrm{~b}$ & $13.12 \mathrm{a}$ \\
\hline 14 Mar. & 4. Initial fruit set & $10.53 \mathrm{c}$ & $11.83 \mathrm{~b}$ & $13.12 \mathrm{a}$ \\
\hline 23 Mar. & 5. Post fruit set & $10.90 \mathrm{ab}$ & $12.11 \mathrm{ab}$ & $13.47 \mathrm{a}$ \\
\hline-- & 6. Control & $10.84 \mathrm{bc}$ & $12.15 \mathrm{ab}$ & $13.35 \mathrm{a}$ \\
\hline \multirow[t]{2}{*}{ Contrasts $^{x}$} & & 6 vs. $4(P=0.06)$ & 6 vs. $3(P=0.06)$ & NS \\
\hline & & 6 vs. $2(P=0.09)$ & 6 vs. $4(P=0.08)$ & \\
\hline
\end{tabular}

${ }^{2} 6 \mathrm{fl} \mathrm{oz} /$ acre formulation $=0.21 \mathrm{oz} /$ acre a.i. $=14.8 \mathrm{~g} \cdot \mathrm{ha}^{-1}$ a.i.

ySC values are corrected for titratable acidity. Means within columns followed by the same letter are not significantly different by Duncan's multiple range test at $P \leq 0.05$. Means presented are for 10 trees per treatment and a 20 fruit sample per tree.

${ }^{x}$ Contrast analysis was run on each EcoLyst treatment versus the control. Only contrasts with $P<0.10$ are listed, along with the associated $P$ value.

Table 7. Effects of EcoLyst rates and application timing on juice soluble solids concentration (SSC) of 'Flame' grapefruit in Loxahatchee, Fla., 1999-2000.

\begin{tabular}{|c|c|c|c|c|}
\hline \multirow[b]{3}{*}{ Treatment } & \multirow{3}{*}{$\begin{array}{c}\text { Date (rate) } \\
{\left[\mathrm{ppm}\left(\mathrm{mg} \cdot \mathrm{L}^{-1}\right)\right]}\end{array}$} & \multicolumn{3}{|c|}{ Harvest date } \\
\hline & & 22 Sept. & 23 Dec. & 7 Feb. \\
\hline & & \multicolumn{3}{|c|}{ SSC $^{z}(\%)$} \\
\hline 1. & 23 Mar. (16) & $8.03 \mathrm{a}$ & $9.41 \mathrm{ab}$ & $9.20 \mathrm{a}$ \\
\hline 2. & 23 Mar. (32) & $7.87 \mathrm{a}$ & $9.32 \mathrm{~b}$ & $8.99 \mathrm{a}$ \\
\hline 3. & 14 Apr. (16) & $7.93 \mathrm{a}$ & $9.42 \mathrm{ab}$ & $9.02 \mathrm{a}$ \\
\hline 4. & 14 Apr. (32) & $7.78 \mathrm{a}$ & $9.57 \mathrm{a}$ & $9.17 \mathrm{a}$ \\
\hline 5. & Control & $8.05 \mathrm{a}$ & $9.35 \mathrm{~b}$ & $9.05 \mathrm{a}$ \\
\hline Contrasts $^{\mathrm{y}}$ & & NS & 5 vs. $4(P=0.02)$ & NS \\
\hline
\end{tabular}

SSC of the control was greater than that of the EcoLyst treatments. There were no significant effects among treatments on 15 Jan. Average SSC was considerably higher at Fellsmere than at Bartow for 'Hamlin' oranges in 2001-02.

In the 2001-02 season, the same 'Hamlin' trees were sprayed as in 2000-01 at Bartow, but EcoLyst had much less effect than in the previous year. In 2001-02, SSC values in controls were higher than those in 2000-01. No cumulative or negative effects of consecutive applications of EcoLyst were apparent.

GrapeFruit RATE AND TIMING EXPERIMENTS. Significant increases in SSC were observed in only one of five trials with grapefruit. This increase was observed in the first year (1999-2000) of the two trials on 'Flame' in Loxahatchee, and was observed only for the $23 \mathrm{Dec}$. harvest (Table 7 ). On this date a $0.22 \%$ SSC increase, compared to controls, was observed from fruit on trees sprayed with 32 ppm EcoLyst at 20\% to 50\% open flowers (14 Apr. 1999). No other data are presented for grapefruit.

SIGNIFICANCE OF THESE FINDINGS. These trials demonstrate that EcoLyst can increase SSC of Florida oranges and grapefruit, but the irregularity of response and rather low level of SSC increase make this material of questionable value to commercial citrus producers. Overall, it appears that EcoLyst application at prebloom up to $25 \%$ open flowers produced the most consistent increase in SSC of oranges but increases never exceeded $0.38 \%$. Our results differ from those of Campbell et al. (1999) and Keithly et al. (2003) who applied EcoLyst during midbloom and observed much greater 
increases in SSC of $0.6 \%$ to $1.2 \%$. In addition, Keithly et al. (2003) found the greatest increase in SSC when EcoLyst was applied at bloom versus pinhead or petal fall growth stages. We do not have a satisfactory explanation for these differences in results. In our studies, rainfall was extremely low during the spring for all 3 years and trees were likely stressed. In the previous studies rainfall was much greater and drought may have been a factor in the lack of EcoLyst response reported here. However, in the one instance in which effect of drought on EcoLyst effectiveness was tested, season-long imposition of water stress on 'Valencia' trees decreased fruit size but there was no EcoLyst effect on stressed or well-watered trees (Stover, unpublished data).

The mode of action of EcoLyst is not known, making it even more difficult to identify scenarios with greater likelihood for successful SSC increase. Eliminating use of the surfactant Silwet L-77 has shown some promise in other studies (Stover, unpublished), but still resulted in irregular responses. Future advancesin understanding physiological response to tertiary amine PGRs may suggest opportunities to enhance the commercial utility of EcoLyst.

\section{Literature Cited}

Campbell, C.A., T. Taggert, and J. Keithly. 1999. A novel plant growth regulator, MBTA, increases soluble solids (Brix) of 'Valencia' orange. Proc. Fla. State Hort. Soc. 112:25-28.

Enviromental Protection Agency. 1999. Pesticide fact sheet, Ecolyst. Il July 2003. <http://www.epa.gov/opprd001/ factsheets/ecolyst.pdf $>$.

Keithly, J.H., H. Yokoyama, and H.W. Gausman. 1991. Regulation of crop growth and yield by tertiary amine bioregulators, $\mathrm{p}$. 223-246. In: H.W. Gausman (ed.). Plant biochemical regulation, Marcel Dekker, N.Y.

Keithly, J.H. ,T.A. Taggart, and C.A Campbell. 2003. Ecolyst: A new plant growth regulator for sweet orange [Citrus sinensis (L.) Osb.]. Proc. Intl. Soc. Citricult. 1: 668-669.

Reitz, H.J. and J.W. Sites. 1948. Relation between positions on the tree and analysis of citrus fruit with special reference to sampling and meeting internal grades. Proc. Fla. Sate Hort. Soc. 54:80-90.

Wardowski, W., J. Soule, W. Grierson, and G. Westbrook. 1995. Florida citrus quality tests. Inst. Food and Agr. Sci., Univ. of Fla., Gainesville. SP99. 